\title{
PENGARUH SUMBER BELAJAR TERHADAP HASIL BELAJAR KEWIRAUSAHAAN DI SMK PEMBINA 1 PALEMBANG
}

\author{
Oleh: Riris Andesta ${ }^{\mathbf{1}}$, Neta Dian Lestari ${ }^{\mathbf{2}}$, Nova Pratiwi ${ }^{\mathbf{3}}$ \\ ririsandesta26@gmail.com ${ }^{1}$, neta_obyta@yahoo.com ${ }^{2}$, vhapratiwi@gmail.com ${ }^{3}$ \\ (Program Studi Pendidikan Akuntansi, FKIP Universitas PGRI Palembang)
}

\begin{abstract}
Abstrak-Penelitian ini bertujuan untuk mengetahui pengaruh sumber belajar terhadap hasil belajar kewirausahaan di SMK Pembina 1 Palembang. Metode penelitian adalah kuantitatif, dengan subjek penelitian siswa kelas XI Akuntansi yang terdiri dari 5 kelas dengan jumlah 155 siswa, sampel dalam penelitian diambil secara Cluster Random Sampling sebanyak 112 siswa. Teknik pengumpulan data sumber belajar menggunakan angket dan hasil belajar mengunakan dokumentasi. Teknik pengujian hipotesis menggunakan uji t dengan hasil penelitian menujukan ada pengaruh sumber belajar terhadap hasil belajar kewirausahaan di SMK Pembina 1 Palembang. pengujian hipotesis $t_{\text {hitung }}$ sumber belajar sebesar 6.337 dengan $t_{\text {tabel }}$ sebesar 1,9815, sehingga hipotesis $H_{o}$ ditolak dan $H_{a}$ diterima. Besarnya pengaruh sumber belajar terhadap hasil belajar kewirausahaan di SMK Pembina 1 yaitu 26,1\%. Penggunaan sumber belajar di dalam proses belajar mengajar sudah dikatagoriakan baik yaitu sebesar $78 \%$ dari semua indikator sumber belajar.
\end{abstract}

Kata Kunci: Sumber belajar, hasil belajar, Kewirausahaan

\begin{abstract}
This study aims to determine the effect of learning resources on entrepreneurial learning outcomes at SMK Pembina 1 Palembang. The research method is quantitative, with the research subjects being students of class XI Accounting consisting of 5 classes with a total of 155 students, the sample in this study was taken by Cluster Random Sampling as many as 112 students. The technique of collecting learning resource data is using a questionnaire and learning outcomes using documentation. The hypothesis testing technique uses the $t$ test with the results of the study showing that there is an influence of learning resources on entrepreneurship learning outcomes at SMK Pembina 1 Palembang. hypothesis testing tcount learning resources of 6337 with ttable of 1.9815, so that the hypothesis Ho is rejected and Ha is accepted. The magnitude of the influence of learning resources on entrepreneurship learning outcomes at SMK Pembina 1 is $26.1 \%$. The use of learning resources in the teaching and learning process has been categorized as good, which is $78 \%$ of all indicators of learning resources.
\end{abstract}

Keywords: Learning resources, learning outcomes, Entrepreneurship

\section{PENDAHULUAN}

Pendidikan

memberikanan bimbingan belajar berupa pembelajaran di kelas, dimana

formal proses pembelajaran di kelas dapat membuat siswa berinteraksi dengan 
guru, selain dengan guru, siswa juga berinteraksi dengan rekan sesama siswa. Setalah mengikuti pembelajaran di kelas untuk melihat tercapai atau tidaknya tujuan pembelajaran, dengan melihat hasil belajar, baik rendah atau tingginya hasil belajar. Faktor yang dapat mempengaruhi hasil belajar, ada sumber belajar, dimana sumber belajar ini dapat membantu proses pembelajaran siswa, contoh dari sumber belajar yang dapat dimanfaatkan siswa bisa melalui buku, majalah, koran, vidio, perpustaka, smartphone, leptop atau komputer serta televisi.

Menurut lismawati, ahmad dan lestari (2019) "Hasil belajar adalah prestasi seseorang dalam merubah tingkah laku dari yang tidak tahu menjadi tahu yang ditandai dengan skala nilai yang mencakup kemampuan kognitif, afektif dan psikomotorik". Hasil belajar memiliki peranan yang sangat penting di dalam proses belajar mengajar karena hasil belajar akan memberikan informasi kepada guru untuk mengetahui sejauh mana kemajuan siswa dalam mencapai tujuan pembelajaran melalui proses belajar mengajar. Informasi dari guru mata pelajaran prakarya dan kewirausahaan untuk hasil belajar siswa kelas XI Akuntansi di SMK Pembina 1 Palembang seluruh siswanya sudah mendapatkan nilai diatas keteria ketuntasan minimal (KKM).
Menurut Qhafi, dkk (2018) "Hasil belajar di pengaruhi oleh faktor internal dan eksternal, faktor internal antara lain, kecerdasan, bakat, kemandirian belajar, displin belajar dan motivasi belajar. Untuk faktor eksternal merupakan faktor yang berasal dari luar diri siswa yaitu berupa lingkungan sekolah, kurilkulum, guru dan sumber belajar". Dari faktor - faktor internal yang sudah disebutkan merupakan faktor yang dapat mempengaruhi hasil belajar siswa, karena sasaran utama di dalam belajar adalah siswa, siswa sebagi subjek dari belajar.

Selain faktor internal ada faktor ekternal yang dapat mempengaruhi hasil belajar kewirausahan, yang dimaksud faktor ekternal adalah penggunan sumber belajar di dalam proses belajar mengajar. Penggunaan sumber belajar dalam pembelajaran dapat meningkat hasil belajar siswa, karen dalam proses pembelajaran penyampian materi kesiswa akan lebih capat dan mudah di pahami. Hal ini sejalan dangan penelitian Farida, dkk (2015) "Menyatakan pemanfaatan sumber belajar dapat mempengaruhi hasil belajar IPS sebesar 76,5\%".

Sumber belajar merupakan sesuatu yang dapat membantu proses pembelajaran siswa, terutama saat ini pembelajaran dilakukan di rumah masing - masing bagimana seorang pendidik harus mampu menyediakan belajar pengalaman yang pencapaian tujuan belajar. dalam proses belajar 
siswa, akan terjadi dengan baik jika diajarkan secara langsung oleh seorang guru, namun di dalam pembelajaran, siswa tidak hanya belajar secara langsung dengan guru, siswa dapat juga belajar mandiri dengan sumber belajar lain, karena sumber belajar tidak hanya didapat dari guru, banyak sumber balajar lain yang dapat dimanfaatkan oleh siswa seperti perpustaka, buku, majalah, koran, vidio, internet, teleivisi, media sosial, kerja kelompok, dan pasar.

SMK Pembina 1 Palembang memiliki sumber belajar bervariasi, dimana siswanya rata-rata memiliki smartphone dan ada beberapa siswa yang memiliki leptop, dengan perangkat tersebut siswa dapat mengakses sumber belajar melalui smartphone atau leptop mereka. Sumber belajar yang terdapat di sekolah misalnya, perpustka sekolah memiliki buku-buku bervariasi, ruang belajar yang memadai dan koparasi sekolah yang dapat digunakan dalam proses pembelajaran.

Berdasarkan uraian diatas maka peneliti berkeingian untuk melakukan penelitan lebih jauh tentang pengaruh sumber belajar terhadap hasil belajar, serta berapa besar pengaruhnya dari variabel tersebut terhadap hasil belajar kewirausahaan. Oleh karena itu peneliti mengambil penelitian dengan judul : "Pengaruh Sumber Belajar Terhadap Hasil Belajar Kewirausahaan Di SMK Pembina 1 Palembang"
Berdasarkan latar belakang diatas, maka rumusan masalah dalam penelitian ini adalah adakah pengaruh sumber belajar terhadap hasil belajar kewirausahaan di SMK Pembina 1 Palembang?. Tujuan didalam penelitian ini untuk mengetahui Pengaruh sumber belajar terhadap hasil belajar kewirausahaan di SMK Pembina 1 Palembang. Penelitian ini diharapkan dapat memberikan manfaat sebagai berikut: (a) penenlitian ini dapat menambah wawasan tentang pengaruh sumber belajar di dalam proses pembelajaran, pentingnya meningkatkan kemandirian belajar siswa serta pengaruhnya terhadap hasil belajar kewirausahaan, (b) dapat menjadi masukan agar memanfaatkan sumber belajar secara optimal dan membiasakan belajar mandiri sehingga hasil belajar menjadi meningkat, (c) untuk menambah pengetahuan dan dapat menjadi bahan acuan untuk melakukan penelitian selanjutnya.

\section{METODE PENELITIAN}

Menurut Sugiyono, (2016) "Variabel penelitian adalah suatu atribut atau sifat atau nilai dari orang, objek atau kegiatan yang mempunyai variasi tertentu yang ditetapkan oleh peneliti untuk dipelajari dan kemudian ditarik kesimpulanya". Adapun yang menjadi variabel dari penelitian ini adalah: Variabel bebas $\left(\mathrm{X}_{1}\right)$ : Sumber Belajar 
Variabel terikat (Y): Hasil belajar kewirausahaan

Sesuai dengan variabel diatas, maka yang menjadi defiinisi oprasional variabel didalam penelitian ini adalah sebagai berikut:

a. Sumber belajar yang dimaksud dalam penelitian ini adalah segala sesuatu yang membantu aktivitas belajar siswa, seperti media cetak, media noncetak, berbentuk fasilitas (perpustaka), berbentukkegiatan (tugas individu dan kelompok), dan lingkungan masyarakat

b. Hasil belajar yang pada penelitian ini adalah hasil belajar kewirausahaan kelas XI Akuntansi, yaitu nilai Raport semester ganjil 2019/2020, di SMK Pembina 1 Palembang.

Menurut Arikunto "metode penlitian adalah cara yang digunakan oleh peneliti dalam mengumpulkan data penelitiannya". Penelitian ini menggunakan metode penelitian kuantitatif dengan pendekatan korelasional.

Menurut Basir \& Amrina (2017) "Populasi adalah keseluruhan atau himpunan objek dengan ciri yang sama, yang telah ditetapkan peneliti untuk dipelajari guna membuat kesimpulan". Populasi di dalam penelitian ini adalah siswa kelas XI Akuntansi di SMK Pembina 1 Palembang, yang memiliki 5 kelas dengan jumlah siswanya 155 siswa.
"Sampel penelitian adalah bagian dari jumlah dan krakteristik yang dimiliki oleh populasi tersebut" Sugiyono (2016). Jumlah sampel yang akan diambil menggunkan rumus Taro Yamane (dalam Riduwan, 2018) sebagai berikut:

Keterangan:

$$
\mathbf{n}=\frac{\mathbf{N}}{\mathbf{N} \cdot \mathbf{d}^{2}+\mathbf{1}}
$$

$$
\begin{aligned}
\mathrm{n}= & \text { Jumlah sampel } \\
\mathrm{N}= & \text { Jumlah Populasi } \\
\mathrm{d}= & \text { presesi (kesalahan sampel) } \\
& \begin{array}{l}
5 \% \\
\text { dalam penlitian ini ditetapkan }
\end{array} \\
\mathrm{n} & =\frac{155}{155.0,05^{2}+1}=\frac{155}{1.387} \\
& =111,75 \text { dibulatkan menjadi } 112
\end{aligned}
$$

Berdasarkan data perhitungan di atas teknik pengambilan sampel dalam penelitian ini menggunakan Cluster Random Sampling yaitu pengambilan data dengan acak. Caranya dengan membuat nomor dan diberikannya di anggota populasi, setelah diberikan nomor ke anggota populasi, nomor tersebut dimasukan kedalam botol kemudian diguncang, kemudian dijatuhkan jika nomor tersebut keluar maka siswa atau siswi tersebut menjadi sampel dalam penelitian ini.

Teknik pengumpulan data pada penelitian ini menggunakan 2 teknik pengumpulan data yaitu angket dan dokumentasi, angket ini digunakan untuk mendapatkan informasi tentang sumber belajar yang dimanfaatkan dalam proses belajarnya, angket sumber belajar dibuat sendiri oleh 
peneliti telah uji valid dan reliabel. Dokumentasi yang digunakan dalam penelitian adalah data tentang keadaan siswa, gambaran umum sekolah, jumlah guru serta nilai raport semester kewirausahaan semester ganjil 2019/2020, kelas XI akuntansi di SMK Pembina 1 Palembang.

Teknik analisis data dalam penelitian ini menggunakan analisis regeresi serderhana, prametik uji t dan uji prasayarat data meliputu uji normalitas dan linieritas. Uji hipotes uji t, untuk melihat pengaruh sumber belajar terhadap hasil belajar kewirausahaan di SMK Pembina 1 Palembang.

\section{HASIL DAN PEMBAHASAN}

\section{Hasil Belajar}

Hasil belajar kewirausahaan diperoleh peneliti dari guru mata pelajaran kewirausahaan, kelas XI Akuntansi, nilai yang dimaksud adalah nilai raport semester ganjil tahun ajaran 2019/2020. Adapun nilai raport siswa dapat di lihat pada tabel berikut:

Tabel 1. Hasil Belajar

\begin{tabular}{|c|c|c|c|c|}
\hline \multicolumn{5}{|c|}{ Rekaptulasi Hasil Belajar Siswa } \\
\hline No & Interval & F & Persentase & Katagori \\
\hline 1 & $86-100$ & 30 & $27 \%$ & Sangat Baik Sekali \\
\hline 2 & $75-85$ & 82 & $73 \%$ & Baik \\
\hline 3 & $60-74$ & 0 & $0 \%$ & Cukup \\
\hline 4 & $45-59$ & 0 & $0 \%$ & Kurang Baik \\
\hline 5 & $\leq 45$ & 0 & $0 \%$ & Sangat Kurang Baik \\
\hline \multicolumn{2}{|c|}{ Jumlah } & 112 & $100 \%$ & \\
\hline
\end{tabular}

Sumber : Tata Usaha SMK Pembina 1 palembang 2019/2020)

Berdasarkan data diatas siswa kelas XI Akuntansi pada mata pelajaran kewirausahaan semua siswanya sudah mencapai KKM pelajaran dan ada beberapa siswa yang memiliki nilai dengan katagori sangat baik. Rata - rata nilai kewirausahaan kelas XI akuntansi sebesar 83.

\section{Uji Normalitas Data}

Tabel 2. Uji Normalitas Data

\begin{tabular}{|c|c|c|c|}
\hline Variabel & Lhitung & $L_{\text {Label }}$ & Keterangan \\
\hline Sumber belajar & 0.0827 & 0.0837 & Normal \\
\hline Hasil Belaiar & 0.0644 & 0.0837 & Normal \\
\hline
\end{tabular}

Sumber: Data Diolah, 2020

Hasil pengujian noramlitas data dengan sampel sebanyak 112 siswa
Jika $\mathrm{L}_{\text {hitung }}$ lebih kecil dari $\mathrm{L}_{\text {tabel }}$ maka data berdistribusi normal dan jika 
$\mathrm{L}_{\text {hitung }}$ lebih besar dari $\mathrm{L}_{\text {tabel }}$ maka data tidak berdistribusi. Dilihat dari hasil $\mathrm{L}_{\text {hitung }}$ sumber belajar, dan hasil belajar lebih kecil dari $\mathrm{L}_{\text {tabel }}$ maka dapat disimpulkan bahwa kedua variabel tersebut berdistribusi normal.

Tabel 3. Uji Linieritas

\begin{tabular}{|c|c|c|c|c|c|c|c|}
\hline \multicolumn{8}{|c|}{ ANOVA Table } \\
\hline & & & $\begin{array}{l}\text { Sum of } \\
\text { Squares }\end{array}$ & $\mathrm{df}$ & $\begin{array}{c}\text { Mean } \\
\text { Square }\end{array}$ & $F$ & Sig. \\
\hline \multirow{5}{*}{$\begin{array}{l}\text { Hasil Belajar * } \\
\text { Sumber Belaiar }\end{array}$} & \multirow{3}{*}{$\begin{array}{l}\text { Between } \\
\text { Groups }\end{array}$} & (Combined) & 604.272 & 39 & 15.494 & 2.046 & .004 \\
\hline & & Linearity & 307.391 & 1 & 307.391 & $\begin{array}{r}40.59 \\
3\end{array}$ & .000 \\
\hline & & $\begin{array}{l}\text { Deviation } \\
\text { from Linearity }\end{array}$ & 296.881 & 38 & 7.813 & 1.032 & .445 \\
\hline & \multicolumn{2}{|c|}{ Within Groups } & 545.219 & 72 & 7.572 & & \\
\hline & \multicolumn{2}{|l|}{ Total } & 1149.491 & 111 & & & \\
\hline
\end{tabular}

Sumber: Data Diolah, 2020

Keteria pengujian linieritas dapat disimpulkan linier untuk yaitu $f_{\text {tabel }}$ nya lebih kecil dari $f_{\text {hitung variabel sumber belajar dan }}$ signifikanya lebih dari 0.005 . kemandirian belajar.

Berdasarkan uji linieritas diatas untuk signifikannya lebih dari 0.005 dan

\section{Analisis Regresi Linier Serderhana} $\mathrm{f}_{\text {tabel }}$ nya lebih besar dari $\mathrm{f}_{\text {hitung }}$ maka

Tabel 4. Analisis Regresi Sederhana

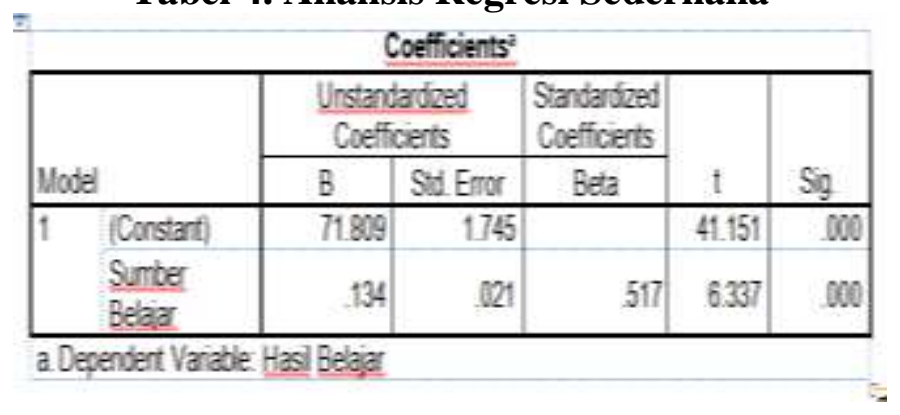

Sumber: Data Diolah, 2020

Berdasarkan tabel diatas dapat diketahui besarnya nilai constant yaitu 71.809 dan nilai koefesiannya yaitu 0.134 sehingga Persamaan regeresi linier serderhana variabel sumber belajar terhadap hasil belajar sebagai berikut:

$$
Y=71.808+0.134 X
$$


Dapat diartikan dari persamaan regersi linier sederhana diatas nilai konstanta $\mathrm{Y}=71.808$ yang berarti bila variabel sumber belajar $=0$ maka hasil berjar siswa akan berkurang sebesar 71.808 sedangkan untuk
Koefesien $\mathrm{X}_{1}=0.134$ dan artinya setiap ada peningkat 1 point sumber belajar maka hasil belajar akan meningkat sebesar 0.134 .

\section{Tabel 5. Uji Hipotesis}

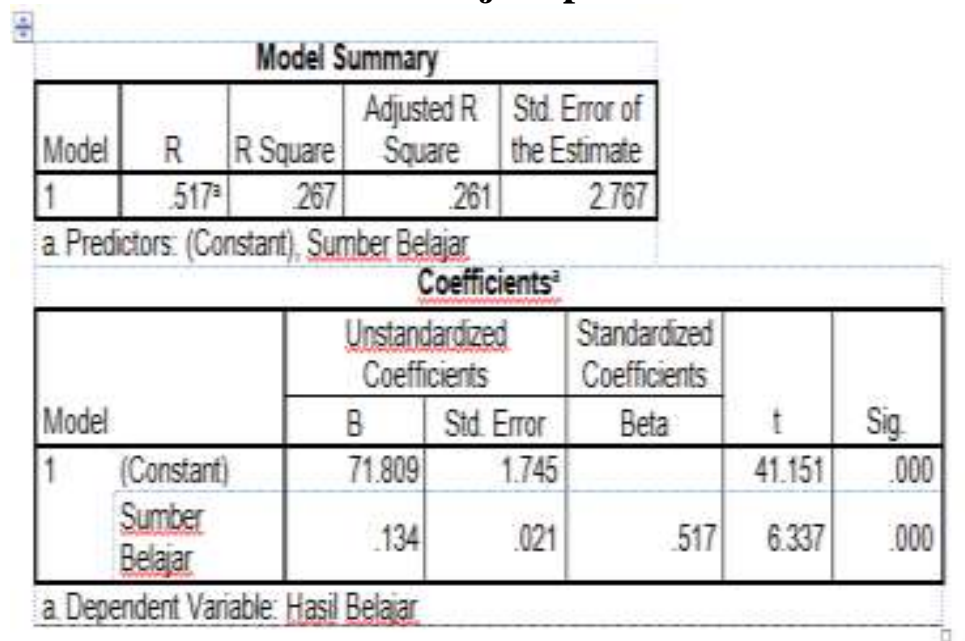

Sumber: Data Diolah, 2020

Mencari $\mathrm{t}$ tabel dengan rumus $\mathrm{dk}=\mathrm{n}-1$ taraf kepercayaan $95 \%$ uji dua pihak. $t$ tabel dalam penelitian ini $\mathrm{dk}=112-1=111$ dengan taraf kepercayaan 95\% sehingga di dapat 1.9815. Dapat di lihat bahwa $t_{\text {hitung }}$ $6.337>\mathrm{t}_{\text {tabel }} 1.981$, sehingga di simpulkan bahwa sumber belajar berpengaruh terhadap hasil berlajar kewirausahaan. Besarnya pengarauh sumber belajar terhadap hasil belajar kewirausahan berdasarkan analisis korelasi yaitu sebesar $26,1 \%$.

\section{Pembahasan}

Berdasarkan data hasil penelitian untuk hasil belajar kewirausahaan memiliki hasil sebagai berikut:

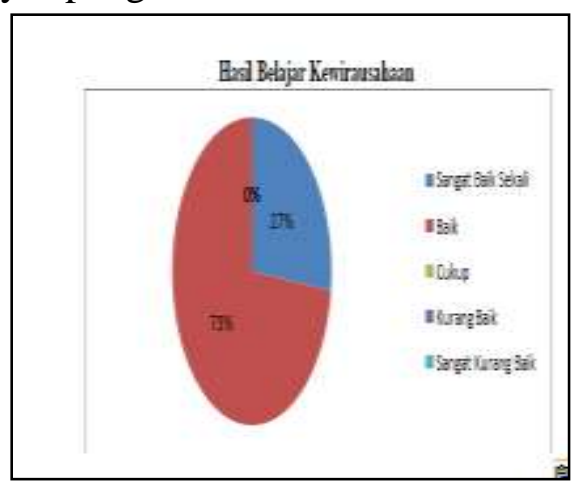

Gambar 1. Hasil Belajar Kewirausahaan (Sumber: Data Diolah, 2020) 
Gambar di atas menjelaskan hasil belajar kewirausahan siswa kelas XI akuntansi di SMK Pembina 1 sudah pada katagori baik karena seluruh siswa mendapatkan nilai diatas keteria ketuntasan minimal. Hasil belajar kewirausahan yang paling besar mendapatkan nilai 90, paling kecil 77 dan untuk rata-rata hasil belajar siswa kelas XI akuntansi yaitu sebesar 83 .

Berdasarkan analisis data, didapati kenyataan bahwa varian sumber belajar pada subjek penelitian di SMK Pembina 1 Palembang sebagai berikut:

a. Sumber Belajar Cetak

Sebanyak $88 \%$ siswa sangat setuju bahwa penggunaan buku paket prakarya dan kewirausahaan dapat menambah ilmu kewirausahaan. Pada pengunaan referensi lain sebagai penunjang pembelajaran kewirausahaan, sebanyak $76 \%$ siswa setuju bahwa penggunaan buku referensi lain dalam pembelajaran keiwirausahaan menambah pengetahuan kewirausahaan.

Membaca koran dapat menambah pengetahuan tentang perkembangan kewirausahaan sebanyak $76 \%$ siswa setuju membaca koran dapat menambah pengetahuan perkembangan kewirausahaan sekarang.

Poster sebagai contoh promosi langsung dari pelajaran kewirausahaan, sebanyak $77 \%$ setuju poster dapat dijadikan contoh promsi langsung pada kewirausahaan.
Menggunakan lebih dari satu sumber belajar dalam pelajaran prakarya dan kewirausahaan dapat menambah pengetahuan dan wawasan, sebanyak $76 \%$ siswa setuju penggunan lebih dari satu sumber belajar dapat menambah pengetahuan dan wawasan. Ketika tidak memiliki buku paket prakarya dan kewirausahaan maka akan mengalami kesulitan belajar, sebanyak 76\% siswa setuju ketika tidak memiliki buku paket prakarya dan kewrirausahan akan mengalami kesulitan belajar.

Berdasarkan pemaparan diatas $78 \%$ siswa setuju penggunaan sumber belajar cetak dalam proses pembelajaran dapat meningkatkan hasil belajar.

\section{b. Sumber Belajar Non Cetak.}

Penggunaan internet dapat menambah wawasan anda tentang kewirausahaan, $79 \%$ menjawab setuju Penggunaan internet dalam proses belajar kewirausahan dapat menambah wawasan anda tentang kewirausahaan. Internet digunakan sebagai perpustakaan digital yang mudah di akses, sebanyak $83 \%$ siswa sangat setuju Internet dapat digunakan sebagai perpustakaan digital yang mudah di akses.

Internet dapat digunakan sumber belajar pengganti saat guru tidak dapat bertatap muka namun tetap melakukan pembelajaran. $65 \%$ siswa setuju Internet dapat digunakan sumber belajar pengganti saat guru tidak dapat bertatap muka namun 
tetap melakukan pembelajaran. Belajar melalui internet dapat memudah memahami meteri pembelajaran kewirausahaan, $77 \%$ siswa menjawab setuju Belajar melalui internet dapat memudah memahami meteri pembelajaran kewirausahaan.

Vidio kewirausahaan di Youtube dapat digunakan sebagai pembelajaran kewirausahaan, sebanyak $77 \%$ siswa setuju vidio kewirausahaan di Youtube dapat digunakan sebagai pembelajaran kewirausahaan. Media sosial dapat digunakan sebagai sumber pembelajaran kewirausahaan, sebanyak $77 \%$ siswa setuju media sosial dapat digunakan sebagai sumber pembelajaran kewirausahaan. Membaca tentang kewirausahaan di internet dan media sosial dapat menjadi referensi dalam berwirausahaan, sebanyak $76 \%$ menjawab setuju membaca tentang kewirausahaan di internet dan media sosial dapat menjadi referensi dalam berwirausahaan.

$$
\text { Media sosial dapat }
$$
dimanfaatkan sebagai media promosi yang baik dalam berwirausaha, $82 \%$ siswa setuju media sosial dapat di manfaatkan sebagai media promosi yang baik dalam berwirausaha. Televisi edukasi mempermudah memahami pembelajaran, sebanyak 59\% siswa menjawab kurang setuju televisi edukasi mempermudah memahami pembelajaran. Televisi dan radio merupakan media yang paling mudah untuk medapatkan informasi tentang kewirausahaan, $61 \%$ siswa menjawab cukup setuju televisi dan radio merupakan media yang paling mudah untuk medapatkan informasi tentang kewirausahaan.

Berdasarkan pemaparan di atas $76 \%$ siswa setuju selain sumber belajar cetak, sumber belajar non cetak dalam proses pembelajaran dapat juga meningkatkan hasil belajar.

\section{c. Sumber Belaja Berbentuk Fasilitas \\ Perpustakaan merupakan tempat} belajar yang memiliki berbagai sumber ilmu,77\% siswa sangat setuju Perpustakaan merupakan tempat belajar yang memiliki berbagai sumber ilmu. Membaca buku yang bekenaan dengan kewirausahaan menambah pengetahuan tentang kewirausaha, $88 \%$ siswa sangat setuju Membaca buku yang bekenaan dengan kewirausahaan menambah pengetahuan tentang kewirausaha.

Jam pelajaran kosong dapat dimanfaatkan untuk membaca buku kewirausahaan di perpustakaan, sebanyak $77 \%$ siswa setuju sehingga dapat diartikan bahwa kebanyakan siswa pada jam pelajaran kosong memanfaatkan jam tersebut untuk membaca buku kewirausahaan di perpustakaan.

Ruang belajar yang ada disekolah (kelas) mendukung siswa berkreativitas tentang kewirausahaan, $76 \%$ siswa setuju ruang belajar yang 
ada disekolah (kelas) mendukung siswa berkreativitas tentang kewirausahaan. Koperasi di sekolah dapat digunakan untuk menambah wawasan kewirausahaan dan tempat prektek berwirausaha, 69\% siswa menjawab cukup setuju koperasi di sekolah dapat digunakan untuk menambah wawasan kewirausahaan dan tempat prektek berwirausaha.

Berdasarkan pemaparan di atas $78 \%$ siswa setuju sumber belajar berbentuk fasilitas dapat meningkatkan hasil belajar. sehingga semakin lengkap fasilitas belajar siswa maka semakin memudahkan siswa dalam proses pembelajaran untuk mendapatkan hasil belajar yang memuasakan.

\section{d. Sumber Belajar Berbentuk Kegiatan}

Tugas kelompok berwirausaha yang diberikan guru dapat memberi wawasan lebih tentang kewirausahaan, sebanyak $73 \%$ siswa cukup setuju tugas kelompok berwirausaha yang diberikan guru dapat memberi wawasan lebih tentang kewirausahaan. Pengetahuan tentang kewirausahaan yang telah di pelajari dapat meningkatkan hasil belajar, sebanyak $79 \%$ siswa setuju pengetahuan tentang kewirausahaan yang telah di pelajari dapat meningkatkan hasil belajar.

Tugas individu pelajaran kewirausahaan yang diberikan guru dapat menambah pengetahuan serta meningkatkan minat berwirausaha, sebanyak $79 \%$ siswa setuju tugas individu pelajaran kewirausahaan yang diberikan guru dapat menambah pengetahuan serta meningkatkan minat berwirausaha.

Berdasarkan pemaparan diatas $77 \%$ siswa setuju sumber belajar berbentuk kegiatan dapat meningkatkan hasil belajar siswa karena siswa lebih aktif untuk mencari pengetahuan - pengetahuan yang baru.

\section{e. Sumber Belajar Berupa Lingkungan Masayarakat \\ Tugas individu berwirausaha} dapat memberikan pemahaman langsung bagimana berwirausaha yang baik, $79 \%$ siswa setuju tugas individu berwirausaha dapat memberikan pemahaman langsung bagimana berwirausaha yang baik. Adanya pasar, toko dan pabrik dapat digunakan sebagai sumber belajar untuk menambah pengetahuan kewirausahaan, sebanyak $79 \%$ siswa setuju adanya pasar, toko dan pabrik dapat digunakan sebagai sumber belajar untuk menambah pengetahuan kewirausahaan. Transaksi yang terjadi di pasar dan toko dapat menjadi contoh yang baik bagimana melayani konsumen dalam kewirausahaan, sebanyak $80 \%$ siswa sangat setuju transaksi yang terjadi di pasar dan toko dapat menjadi contoh yang baik bagimana melayani konsumen dalam kewirausahaan.

Berdasarkan pemaparan diatas $79 \%$ siswa setuju sumber belajar 
berupa lingkungan masayarakat juga dapat dijadikan sebagai sumber belajar secara langung oleh siswa.

Hasil penelitian menunjukan bahwa sumber belajar berpengaruh signifikan terhadap hasil belajar kewirausahaan di SMK Pembina 1 Palembang. Hasil penelitian ini mendukung hipotesis yang diajukan dimana sumber belajar berpengaruh signifikan terhadap hasil belajar kewirausahaan di SMK Pembiana 1 Palembang. Hasil perhitungan diperoleh nilai $\mathrm{t}_{\text {hitung }}=6.337$ dan $\mathrm{t}_{\text {tabel }}$ 1.981, dimana $t_{\text {hitung }}>t_{\text {tabel }}$ yang berarti Ha diterima atau dengan kata lain secara pengujian hipotesi berpengaruh, untuk mencari $t_{\text {tabel }}$ dengan rumus $\mathrm{dk}=\mathrm{n}-1$ taraf kepercayaan $95 \%$ uji dua pihak. $\mathrm{t}_{\text {tabel }}$ dalam penelitian ini $\mathrm{dk}=112-1=$ 111 dengan taraf kepercayaan 95\% sehingga didapat 1.9815 . besarnya pengaruh sumber belajar terhadap hasil belajar kewirausahaan di SMK Pembina 1 Palembang yaitu sebesar $26.1 \%$ dan sisanya dipengaruhi oleh faktor lain .

Hasil perhitungan uji regeresi serderhana yaitu didapatkan persamaan $\mathrm{Y}=71.808+0.134 \mathrm{X}$. Dapat diartikan dari persamaan regersi linier sederhana diatas nilai konstanta $\mathrm{Y}=71.808$ yang berarti bila variabel sumber belajar $=0$ maka hasil berjar siswa akan berkurang sebesar 71.808 sedangkan untuk Koefesien $\mathrm{X}_{1}=0.134$ dan artinya setiap ada peningkat 1 point sumber belajar maka hasil belajar akan meningkat sebesar 0.134

Sejalan dengan hasil penelitian Solikhah (2018) "pengaruh pemanfaatan sumber belajar dan motivasi terhadap hasil belajar siswa pada mata pelajaran ekonomi". Hasil penelitian menunjukan terdapat pengaruh positif pemanfaatan sumber belajar terhadap hasil belajar siswa pada mata pelajaran ekonomi.

Hasil belajar dapat dimaknai kemampuan yang dimiliki siswa setelah memperoleh pengalaman pembelajaran. pengalaman pembelajaran yang di peroleh siswa mencakupi ranah kognitif, efektif dan psikomotorik. Hasil belajar dipengaruhi oleh faktor internal dan ekternal yang dimana faktor salah satu faktor ekternal adalah sumber belajar.

Penggunaan sumber belajar di dalam pembelajaran dapat meningkat hasil belajar siswa, di karenakan dalam proses pembelajaran penyampian materi kesiswa akan lebih capat dan mudah di pahami. Sumber belajar dapat diartikan sebagai orang, data, benda atau pun yang lainnya yang dapat membantu proses pembelajaran. sejalan pendapat diatas Menurut Prastowo (2018:28) "Sumber belajar pada hakikatnya adalah segala sesuatu (benda, data, fakta, ide, orang, dan lain sebagianya) yang bisa menimbulkan proses belajar". 


\section{KESIMPULAN}

Berdasarkan hasil analisis data penelitian yang telah dilakukan mengenai Pangaruh Sumber Belajar Terhadap Hasil Belajar Kewirausahaan di SMK Pembina 1 Palembang dapat disimpulkan sebagai berikut:

Ada pengaruh sumber belajar terhadap hasil belajar kewirausahaan di SMK Pembina 1 Palembang. pengujian hipotesis $t_{\text {hitung }}$ sumber belajar sebesar 6.337 dengan $t_{\text {tabel }}$ sebesar 1,9815, sehingga hipotesis $\mathrm{H}_{\mathrm{o}}$ ditolak dan $\mathrm{H}_{\mathrm{a}}$ diterima. Besarnya pengaruh sumber belajar terhadap hasil belajar kewirausahaan di SMK Pembina 1 yaitu $26,1 \%$. Penggunaan sumber belajar di dalam proses belajar mengajar sudah dikatagoriakan baik yaitu sebesar $78 \%$ dari semua indikator sumber belajar.

Berdasarkan kesimpulan hasil penelitian ini maka peneliti memberikan saran sebagai berikut:

1. Bagi siswa di harapakan agar lebih mengoptimalkan pemanfaatan sumber belajar yang ada sehingga pembelajaran tidak hanya terpaku pada guru. Siswa dapat belajar memanfaatkan buku paket, perpustakan, internet dan media sosial, koran dan poster sebagai sumber belajar selain.

2. Bagi guru diharapkan dapat membimbing siswa agara lebih memanfaatkan sumber belajar yang ada di lingkungan.
3. Bagi sekolah dapat digunakan sebagai masukan untuk senatiasa dalam meningkatkan sarana sumber belajar siswa dan meningkatkan kedisplinan agar mendorong siswa lebih mandiri.

4. Bagi peneliti lain dapat di jadikan bahan referensi dalam melakukan penelitian selanjutnya.

\section{DAFTAR PUSTAKA}

Arikunto, S. (2014). Prosedur Penelitian. Jakarta: Renika Cipta.

Basir, D., \& Amrina, D. E. (2017). Pengantar Metode Penelitian Pendidikan. Palembang: Universitas Sriwijaya.

Farida, I., \& Salim, I. (2015). Pengaruh Motivasi Belajar Dan Pemanfaatan Sumber Belajar Terhadap Hasil Belajar Siswa SMP Negeri 11 Pontianak. Jurnal Pendidikan dan Pembelajaran Khatulistiwa, 4(5). https://jurnal.untan.ac.id/index.ph p/jpdpb/article/view/10127

Lismawati, L., Ahmad, S., \& Lestari, N. D. (2019). Hubungan Antara Pendekatan Pembelajaran Peer Group Dengan Hasil Belajar Siswa Pada Mata Pelajaran Ekonomi SMA Negeri 1 Palembang. PROMOSI: Jurnal Program Studi Pendidikan Ekonomi, 7(2). https://ojs.fkip.ummetro.ac.id/inde x.php/ekonomi/article/view/2514

Prastowo, A. (2018). Sumber Belajar \& Pusat Sumber Belajar. Depok: Prenadamedia Group.

Qahfi, M., Norhayatun, N., \& Fitriaty, M. (2020). Pengaruh Sumber Belajar Dan Kemandirian Belajar Terhadap Hasil Belajar Siswa. Jurnal Paedagogie Media 
Kependidikan, Keilmuan dan Keagamaan, 6(1), 25-33.

http://ejurnal.stkipmsampit.ac.id/i ndex.php/Pendidikan/article/view/ 106.

Solikhah, Anggriani (2018) Pengaruh Pemanfaatan Sumber Belajar Dan Motivasi Terhadap Hasil Belajar Siswa Pada Mata Pelajaran Ekonomi : Survey Pada Siswa Kelas XI IIS di SMA Negeri Kota Bandung. S1 thesis, Universitas Pendidikan Indonesia http://repository.upi.edu/34938/ Sugiyono. (2016). Metode Penelitian Pendidikan. Bandung: Alfabeta. 